\title{
Vacant Bivalve Boreholes Increase Invertebrate Species Richness in a Physically Harsh, Low Intertidal Platform
}

\author{
María Bagur ${ }^{1,2, *}$, Jorge L. Gutiérrez ${ }^{2,3}$ () , Lorena P. Arribas ${ }^{4}$ and M. Gabriela Palomo ${ }^{2,5}$ \\ 1 Centro Austral de Investigaciones Científicas (CADIC-CONICET), Ushuaia V9410CAB, Argentina \\ 2 Grupo de Investigación y Educación en Temas Ambientales (GrIETA), Estación Biológica Las Brusquitas, \\ San Eduardo del Mar B7783ADE, Argentina; jgutierrez@grieta.org.ar (J.L.G.); \\ gpalomo@macn.gov.ar (M.G.P.) \\ 3 Instituto de Geología de Costas y del Cuaternario (IGCyC, UNMdP/CIC) \& CONICET, Universidad \\ Nacional de Mar del Plata, Mar del Plata B7602AYL, Argentina \\ 4 Instituto de Biología de Organismos Marinos (IBIOMAR-CONICET), Puerto Madryn U9120ACV, Argentina; \\ lorearribas@gmail.com \\ 5 Museo Argentino de Ciencias Naturales “Bernardino Rivadavia” (MACN-CONICET), \\ Buenos Aires 1405DJR, Argentina \\ * Correspondence: mbagur@cadic-conicet.gob.ar; Tel.: +54-2901-422310 (ext. 130)
}

Received: 15 February 2019; Accepted: 27 February 2019; Published: 7 March 2019

\begin{abstract}
Ecosystem engineers can modulate harsh abiotic conditions, thus creating habitat for species that cannot withstand the local environment. In this study, we investigated if vacant boreholes created by the rock-boring bivalve Petricola dactylus increase species richness in the low intertidal zone of a Patagonian rocky shore characterized by intense hydrodynamic forcing and sediment scour. Invertebrate species richness was three times higher in engineered than unengineered habitats (i.e., with and without Petricola boreholes, respectively) and the increase in species richness was area-independent. The most prevalent species in unengineered areas showed strong adhesion mechanisms, whereas infaunal and vagile species were mostly restricted to boreholes. The positive influence of engineered microhabitats on species richness can largely be attributed to amelioration of physical conditions, particularly a reduction in hydrodynamic forces and sediment trapping/stabilization within boreholes. We conclude that vacant boreholes are essential microhabitats for the maintenance of biodiversity within the otherwise inhospitable low intertidal zone.
\end{abstract}

Keywords: ecosystem engineer; rock-boring; boreholes; harsh environment; low intertidal; rocky shores; increase species richness; Petricola dactylus

\section{Introduction}

Local abiotic conditions are often suitable to a fraction of the species in the broader species pool (e.g., [1,2]). In these cases, biodiversity is frequently enhanced by species that structurally modify the environment and, in so doing, create microhabitats where the impact of abiotic conditions becomes reduced (e.g., [3-5]). These physical ecosystem engineers (sensu [6,7]) can create favorable microhabitats for other organisms either via their own structures (e.g., cushion plants that retain moisture and modulate extreme soil temperatures to other plants in otherwise unsuitable alpine environments [3]) or their activities (e.g., rabbits that excavate burrows, and thus create thermoregulatory retreats for lizards in thermally variable and otherwise inhospitable Mediterranean 
pastures [8]). Oftentimes, many species in a locale occur in strict association with the microhabitats engineered by one or a few species (e.g., [3-5]).

Physically engineered microhabitats are known to be critical for biodiversity in rocky intertidal shores (e.g., [4,5,9-11]), where wave exposure, desiccation, and temperature often exceed species tolerance limits [12-14]. Therefore, many of the species inhabiting this environment rely on the creation of protected microhabitat by a few tolerant and often spatially dominant sessile species (e.g., mussels, tunicates, seaweeds $[4,5,10,11,15])$. Typically, the facilitative effects of physically engineered microhabitats on other species have been reported to occur at high intertidal elevations, where the impacts of desiccation and temperature variations are expected to be higher (e.g., $[9,16])$. In contrast, the lower intertidal zone has been generally considered as a physically "benign" habitat where biodiversity is usually controlled by biotic factors (predation and space competition [17-19]) and physical habitat amelioration by ecosystem engineers becomes less important $[9,16,20]$.

Here we evaluate if the microhabitats created by a physical ecosystem engineer-the rock-boring bivalve, Petricola dactylus - positively contribute to species richness in the physically harsh, low intertidal zone of a southwestern Atlantic rocky shore. Petricola dactylus is a mechanical borer that inhabits soft rock in low intertidal and subtidal habitats of the southwestern Atlantic and southeastern Pacific, from Uruguay to Southern Chile [21-23]. The boreholes left vacant by dead P. dactylus reach high densities at our study site (often more than 600 boreholes $\mathrm{m}^{-2}$ ) and are prominent structural elements in otherwise barren rock surfaces (Figure 1b). Since the microhabitat within boreholes is protected from extreme hydrodynamic forces and scour and, as a consequence, retains sediments (i.e., a critical habitat element for the infauna, Figure 1c), we predicted that it will positively contribute to the overall invertebrate species richness of the low intertidal zone and, to an extent, an area larger than what it adds to the seabed. To test this prediction, we compared invertebrate species richness in patches with and without $P$. dactylus boreholes, and evaluated if differences in species richness are proportional to the amount of surface area sampled in each patch type. Additionally, we tested if the species occurring in strict association to boreholes are a subset of those occurring in mussel beds at midshore elevations. 


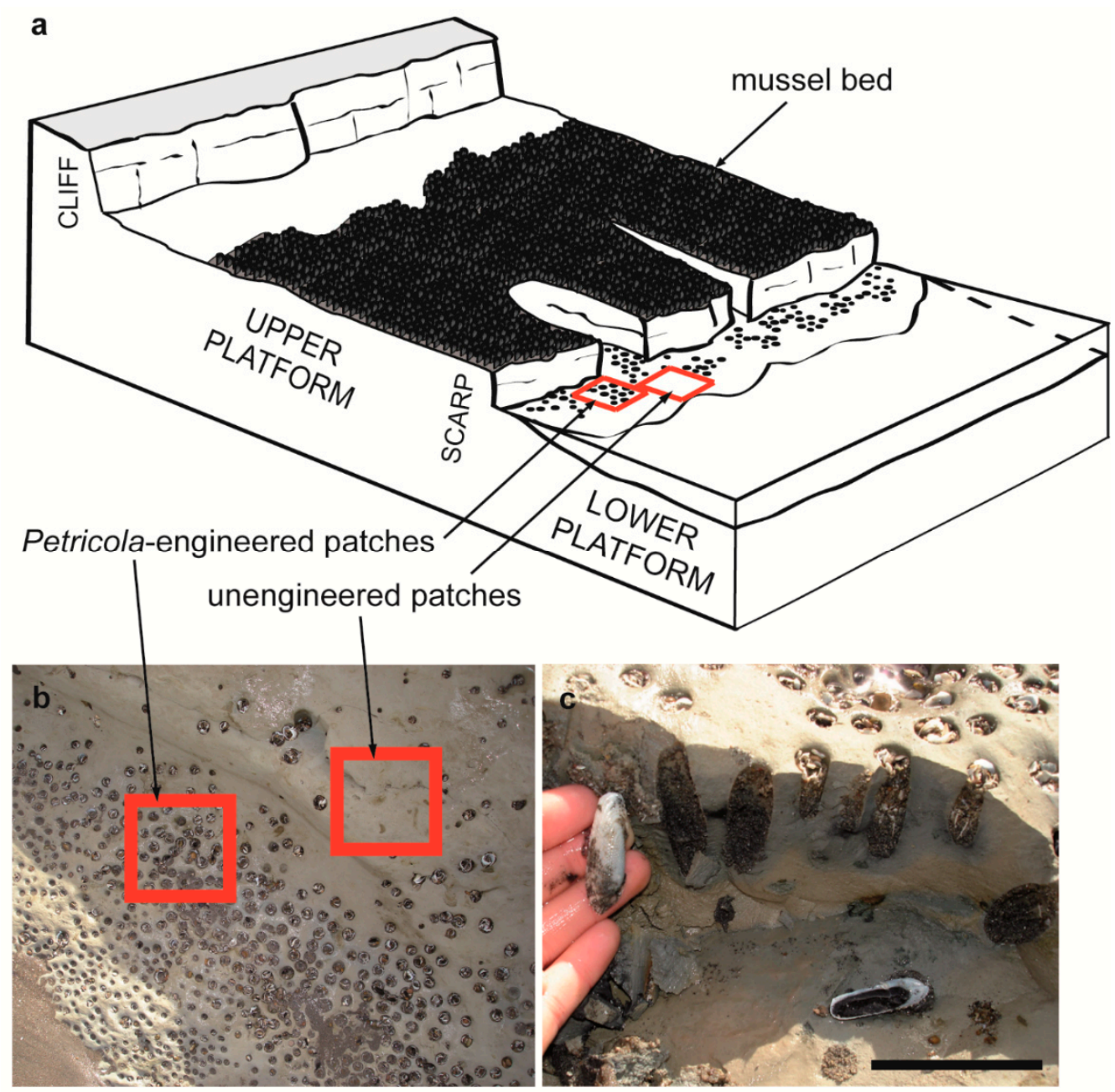

Figure 1. (a) Scheme of the horizontal shore platform at El Espigón, showing upper and lower platforms separated by a scarp. Arrows show the position of the mussel beds, Petricola-engineered patches (with boreholes) and unengineered patches (without burrows). (b) Close view of Petricola-engineered and unengineered patches. The red squares are scaled, $10 \mathrm{~cm}$ side quadrats as those used for sampling. (c) Lateral view of boreholes filled with sediment and empty Petricola dactylus shells (the rock was cut perpendicular to the surface). Scale is $5 \mathrm{~cm}$.

\section{Materials and Methods}

\subsection{Study Site and Organisms}

Samplings were conducted in a rocky platform at El Espigón, Río Negro Province, Argentina $\left(41^{\circ} 07^{\prime} \mathrm{S}, 63^{\circ} 00^{\prime} \mathrm{W}\right)$, between February 2010 and May 2018. This is an extensive (600 $\mathrm{m}$ width) horizontal or Type B platform (see [24]) showing a vertical seaward scarp (ca. $2 \mathrm{~m}$ high) that sets the limit between the upper and lower intertidal levels (hereafter upper and lower platforms, Figure 1a). This platform lies at the base of a high, active cliff (up to $65 \mathrm{~m}$ height [25]) and both the cliff and the platform are composed of fine- to midgrained sandstones and limestone, corresponding to the geological unit locally known as Río Negro Formation [26]. Tides are semidiurnal and macrotidal (4.33 m max. amplitude; Servicio de Hidrografía Naval, Argentina, www.hidro.gov.ar).

The upper platform is characterized by extensive mussel beds (mean densities vary between 36,000 and 55,000 ind. $\mathrm{m}^{-2}$, [27]). The dominant mussel species in this region is Brachidontes rodriguezii, though scattered individuals of a morphologically similar species, Perumytilus purpuratus (also referred to in the literature as Brachidontes purpuratus), are often found within B. rodriguezii beds (both species coexist 
between $41^{\circ}$ and $43^{\circ} \mathrm{S}$; see [28-30]). These mussels are important ecosystem engineers in southwestern Atlantic rocky intertidal shores, as their beds provide critical habitats to other organisms $[4,5,11,28]$.

The lower platform, on the other hand, is essentially flat and barren (Figure S1). Apart from scattered rock fractures, the only structural elements at this shore level are the perforations produced by Petricola dactylus. Most of these boreholes are structural legacies resulting from P. dactylus death (just $2 \%$ of boreholes are inhabited by living specimens). They occur aggregated into dense patches $\left(630 \pm 329\right.$ ind. $\mathrm{m}^{-2}$; Figure 1b) and are often occupied by individual mussels (although mussels are generally smaller than those in the upper platform, pers. obs.) and other invertebrates as well. This zone is characterized by intense wave action (the scarp induces local wave energy dissipation and reflection; see [31,32]) and scour due to sand and gravel transport (Figure S1). This shore level becomes exposed only during very low $(<0.60 \mathrm{~m}$ ) tides (mean low tide level is $0.70 \mathrm{~m}$; Servicio de Hidrografía Naval) and can be temporarily covered by sand and/or gravel (Figure S1, pers. obs.). Hydrodynamic forcing and sediment scour are the only logical alternatives to explain the predominance of bare rock surfaces in the low platform (see also Figure S1). Indeed, desiccation is expected to be insignificant at this shore level since emersion takes place 8-21 days per month (mean $15.25 \pm 4.11$ ) but for short periods (less than $2 \mathrm{~h}$ ) that do not necessarily coincide with desiccative conditions (e.g., daytime, high irradiation, low ambient moisture). Grazers and predators are also unexpected to produce bare rock surfaces in this area as the removal of dominant sessile species by these consumers should still allow colonization by competitively inferior, consumer-resistant, and/or nonfood species (e.g., [33,34]).

\subsection{Sampling}

To evaluate if boreholes created by $P$. dactylus can increase species richness, we measured macroinvertebrate species presence in engineered (i.e., with boreholes) and unengineered (i.e., without boreholes) patches at the lower platform. Engineered and unengineered patches were randomly sampled during 2010 (February, May, July, September, and November), 2011 (March and June), and 2018 (May) using $10 \times 10 \mathrm{~cm}$ quadrats $(\mathrm{n}=65$, between 5 and 25 samples per patch type per date). The unengineered patches sampled here were located amongst boreholes (see Figure $1 \mathrm{~b}$ ) and samples from each patch type came from the same tidal level and position on the shore. The number of samples taken differed between sampling dates because the time available for sampling varied with the duration of the tidal emersion period. Nonetheless, the number of samples taken from engineered and unengineered patches was the same in each sampling date. Samples from engineered patches included invertebrates inside boreholes and those occurring on the rock surface between neighboring boreholes. A laboratory spatula was used to remove the sediments and invertebrates from inside the boreholes. Invertebrates visible on the rock surface or inside the boreholes were either identified in situ or collected and preserved in $96 \%$ ethanol for subsequent identification in the laboratory. The same methodology was applied for the invertebrates on the rock surface in the unengineered habitat. The number of boreholes and their diameter were registered in all the samples taken from engineered patches.

Additionally, we sampled the mussel beds at the upper platform to compare their invertebrate species composition with that of Petricola-engineered areas. Mussels and their associated sediments were sampled in 2009 (September), 2010 (February, May, July, and November), and 2011 (March, June, and August) using cylindrical cores $(10 \mathrm{~cm}$ diameter, 8 replicates per date, $\mathrm{n}=64)$. These samples were preserved in $96 \%$ ethanol, transported to the laboratory, and sieved (500 $\mu \mathrm{m}$ mesh) to separate and identify the macrofauna.

\subsection{Data Analysis}

Species richness (Sobs) in Petricola-engineered and unengineered habitat at the lower platform was quantified with sample-based species accumulation curves constructed by means of rarefaction techniques [35]. Species accumulation was first evaluated as a function of the number of samples collected in each habitat type $(n=65)$. Then, species accumulation was evaluated as a function of 
the rock surface area of boreholes in Petricola-engineered patches and compared with areal species accumulation in unengineered rock patches. Invertebrate samples were standardized to borehole surface area as follows:

(a) The rock surface area added by individual boreholes was estimated as the surface area of a cylinder, based on field measurements of borehole diameter (see above) and assuming a uniform borehole depth of $4 \mathrm{~cm}$. Such a depth is about the maximum depth observed for boreholes at our study site (see also Figure 1b), and thus provides an estimate of the maximum rock surface area potentially added by boreholes (i.e., most likely an overestimate of the actual surface area).

(b) Data from individual boreholes (3 to 11) were grouped adding to an estimated maximum surface area of $100 \mathrm{~cm}^{2}$ per group (76 groups, mean $=99.8 \mathrm{~cm}^{2}, \mathrm{SD}=7.8$ ), thus matching the surface area of unengineered rock samples (i.e., $10 \mathrm{~cm}$ side quadrats). Invertebrate species composition was established at the group level. Groups were used as grain (areal units of observation; see [36]) when constructing accumulation curves for the species sampled from boreholes. As the surface area of boreholes was likely overestimated here (see (a)), our estimates of species accumulation per surface area unit can be considered conservative.

Confidence intervals (95\%) for Sobs were calculated based on the unconditional variance estimate developed by Colwell et al. [37]. Nonoverlapping confidence intervals were considered to indicate significant differences between pairs of Sobs values. This approach is normally used as a simple but conservative criterion of statistical difference in the absence of any computationally practical standard test to compare Sobs values [37,38]. Moreover, a $t$-test for unequal variances (or "Welch's approximate $\left.t^{\prime \prime},[39]\right)$ was used to compare the mean number of species per sample in engineered and unengineered patches and in boreholes versus unengineered rock surface area. To evaluate whether our sampling effort was enough to obtain reliable estimates of species richness in each habitat type (Petricola-engineered, unengineered, and mussel beds), we compared Sobs values with the Chao 2 estimate of the total number of species likely to be observed in the community [3,40]. EstimateS 9.1.0 [38] was used to construct rarefied species accumulation curves and to estimate Chao 2.

Differences in the identity of species associated with the two engineers (Petricola dactylus at the lower platform and mussels at the upper platform) were quantified as the paired overlap (PO [41], see also [5]). PO was calculated for the original data matrix and for 1000 randomized matrices of the same size. The species in habitat $j$ (Petricola-engineered) were considered a significant subset of those in habitat $i$ (mussel-engineered) if the observed POij lay within the upper $95 \%$ percentile of the frequency distribution of POij values of the randomized matrices. Randomized matrices and their associated PO values were obtained using the software ANINHADO [42].

\section{Results}

\subsection{Invertebrate Species Composition and Richness in SAMPLEs from Petricola-Engineered and Unengineered Patches}

Twenty-one species were found at the lower platform (Table 1). Fourteen species from eight different taxonomic groups were exclusively found in Petricola-engineered patches. In contrast, only one species, the chiton Plaxiphora aurata, was exclusively found in unengineered patches. Six species were shared between these two habitat types (Table 1). 
Table 1. Species found at the lower platform in unengineered and Petricola-engineered patches and at the upper platform in mussel-engineered patches (i.e., mussel beds).

\begin{tabular}{|c|c|c|c|c|c|}
\hline Species & $\operatorname{Taxa}^{1}$ & Adhesion $^{2}$ & Unengineered & Petricola-Engineered & Mussel-Engineered \\
\hline Parabunodactys imperfecta & $\mathrm{CnA}$ & YES & $x$ & $x$ & \\
\hline Acotylea indet. & $\mathrm{P}$ & NO & & $x$ & \\
\hline Lumbrineris $s p$. & $\mathrm{AP}$ & NO & & $X$ & $\mathrm{X}$ \\
\hline Perinereis sp. & $\mathrm{AP}$ & $\mathrm{NO}$ & & $x$ & $x$ \\
\hline Syllis gracilis & $\mathrm{AP}$ & $\mathrm{NO}$ & & $x$ & $x$ \\
\hline Syllis prolixa & $\mathrm{AP}$ & $\mathrm{NO}$ & & $x$ & $x$ \\
\hline Cirratulidae & $\mathrm{AP}$ & NO & & $X$ & \\
\hline Protoarcinella uncinata & $\mathrm{AP}$ & $\mathrm{NO}$ & & $X$ & $x$ \\
\hline Platynereis sp. & $\mathrm{AP}$ & $\mathrm{NO}$ & & & $x$ \\
\hline Boccardia polybranchia & $\mathrm{AP}$ & NO & & & $\mathrm{X}$ \\
\hline Capitella capitata? & $\mathrm{AP}$ & $\mathrm{NO}$ & & & $x$ \\
\hline Nereididae (Allita?) & $\mathrm{AP}$ & $\mathrm{NO}$ & & & $x$ \\
\hline Brachidontes rodriguezii & MB & YES & $\mathrm{X}$ & $\mathrm{X}$ & $x$ \\
\hline Petricola lapicida & MB & NO & & $\mathrm{X}$ & \\
\hline Mytilus edulis & MB & YES & & & $x$ \\
\hline Plaxiphora aurata & MP & YES & $x$ & & \\
\hline Siphonaria lessoni & MG & YES & & & $\mathrm{X}$ \\
\hline Themiste alutacea & $\mathrm{S}$ & NO & & $\mathrm{X}$ & \\
\hline Nemertea indet. & $\mathrm{N}$ & NO & & $\mathrm{X}$ & $x$ \\
\hline Chironomidae indet. & ID & YES & $\mathrm{X}$ & $x$ & $x$ \\
\hline Balanus glandula & $\mathrm{CrCi}$ & YES & $x$ & $\mathrm{X}$ & $x$ \\
\hline Copepoda indet. & $\mathrm{CrCo}$ & NO & & $X$ & \\
\hline Hyale grandicornis & CrA & NO & & & $\mathrm{X}$ \\
\hline Melitidae indet. & CrA & $\mathrm{NO}$ & & & $x$ \\
\hline Ampithoidae indet. & CrA & $\mathrm{NO}$ & & & $x$ \\
\hline Corophiidae indet. & $\mathrm{CrA}$ & $\mathrm{NO}$ & $x$ & $x$ & $x$ \\
\hline Exosphaeroma sp. & $\mathrm{CrI}$ & $\mathrm{NO}$ & $x$ & $x$ & $x$ \\
\hline Tanais sp. & $\mathrm{CrT}$ & $\mathrm{NO}$ & & $X$ & $x$ \\
\hline Cyrtograpsus altimanus & $\mathrm{CrD}$ & $\mathrm{NO}$ & & $\mathrm{X}$ & $\mathrm{X}$ \\
\hline Platyxanthus crenulatus & $\mathrm{CrD}$ & $\mathrm{NO}$ & & $x$ & \\
\hline Total & & & 7 & 20 & 22 \\
\hline
\end{tabular}

${ }^{1}$ Taxa-AP: Annelida Polychaeta, CnA: Cnidaria Anthozoa, CrA: Crustacea Amphipoda, CrCi: Crustacea Cirripedia, CrCo: Crustacea Copepoda, CrD: Crustacea Decapoda, CrI: Crustacea Isopoda, CrT: Crustacea Tanaidacea, ID: Insecta Diptera, MB: Mollusca Bivalvia, MG: Mollusca Gastropoda, MP: Mollusca Polyplacophora, N: Nemertea, P: Platyhelminthes, S: Sipunculida. ${ }^{2}$ Adhesion-YES: Species that permanently or temporarily attach to the rock by means of secretions, NO: species showing no attachment.

The species accumulation curve obtained for the unengineered habitat approached the asymptote and observed species richness values (Sobs) were close to the Chao 2 richness estimator, which suggests that this habitat was sampled thoroughly enough to characterize its species richness (Figure 2a). On the contrary, the species accumulation curve corresponding to Petricola-engineered patches did not reach the asymptote and Sobs values were lower than the Chao 2 estimate (Figure 2a), which suggests additional species should be found with further sampling. Sobs was significantly higher in the Petricola-engineered than unengineered patches (no overlap between confidence intervals; see Figure 2a). The mean number of species per sample was higher in engineered patches (mean $1.92 \pm 2.38)$ than in unengineered ones $(0.38 \pm 0.49)$ (Welch's $t$-test: $t=7.31, d f=89, P<0.001)$.

Fifty-six out of 65 sampling quadrats in the Petricola-engineered patches ( $86 \%$ ) showed at least one invertebrate species. In contrast, invertebrates were found just in 17 out of the 65 quadrats from unengineered patches $(26 \%)$. The most prevalent species in the unengineered habitat were the mussel Brachidontes rodriguezii, the barnacle Balanus glandula, and the chiton Plaxiphora aurata $(15,9$, and $5 \%$ of samples, respectively; Figure 3). B. rodriguezii was also the most prevalent species in Petricola-engineered patches (78\% of samples), followed by the polychaetes Lumbrineris sp., Syllis gracilis, and S. prolixa (26, 23, and 14\% of samples, respectively; Figure 3). Nine of the species sampled in Petricola-engineered patches were found only one time (in just one quadrat) during the sampled period. 

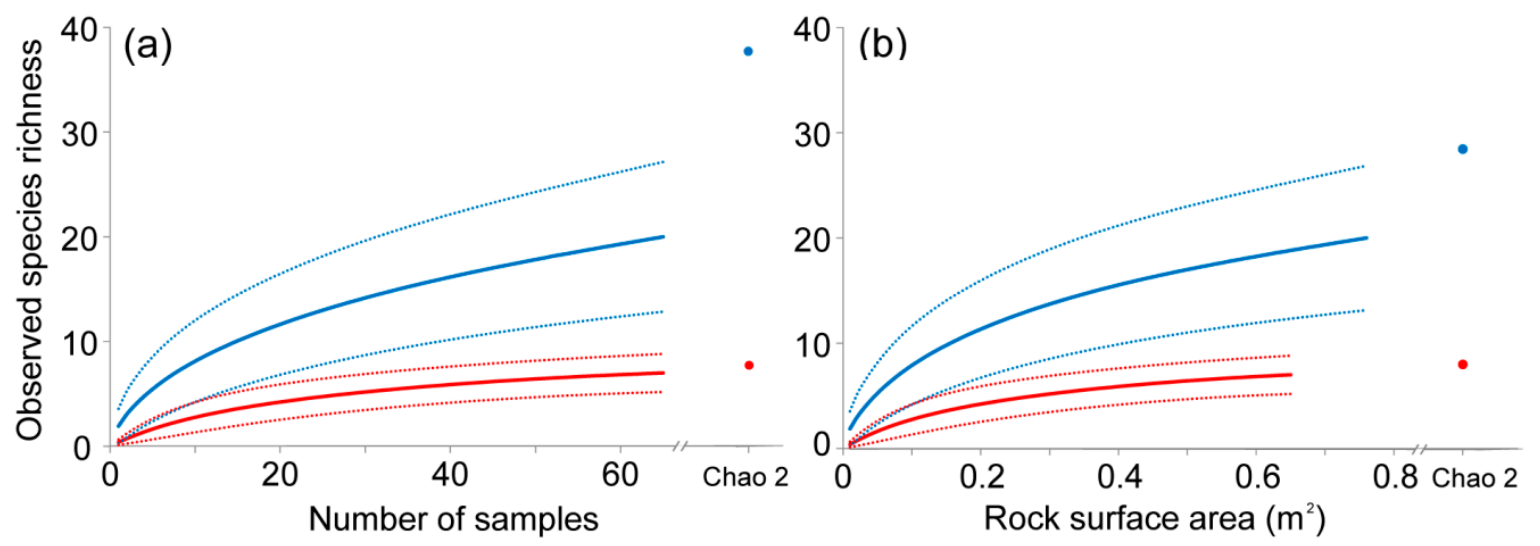

Figure 2. (a) Species accumulation curves (continuous lines) for Petricola-engineered (blue) and unengineered (red) patches at the lower platform with their respective $95 \%$ confidence intervals (dashed lines). The observed species richness (Sobs) for 65 samples is shown for both habitats together with the values of the Chao 2 estimate of total species richness (blue and red circles for Petricola-engineered and unengineered patches, respectively). (b) Species accumulation curves and their confidence intervals for species present inside Petricola boreholes in engineered patches (blue) and on the rock surface in unengineered patches (red) in relation to the rock surface area. The curve for boreholes extends further than that of unengineered rock surfaces because of differences in surface area sampled (boreholes = $0.76 \mathrm{~m}^{-2}$, unengineered rock surface $=0.65 \mathrm{~m}^{-2}$ ).

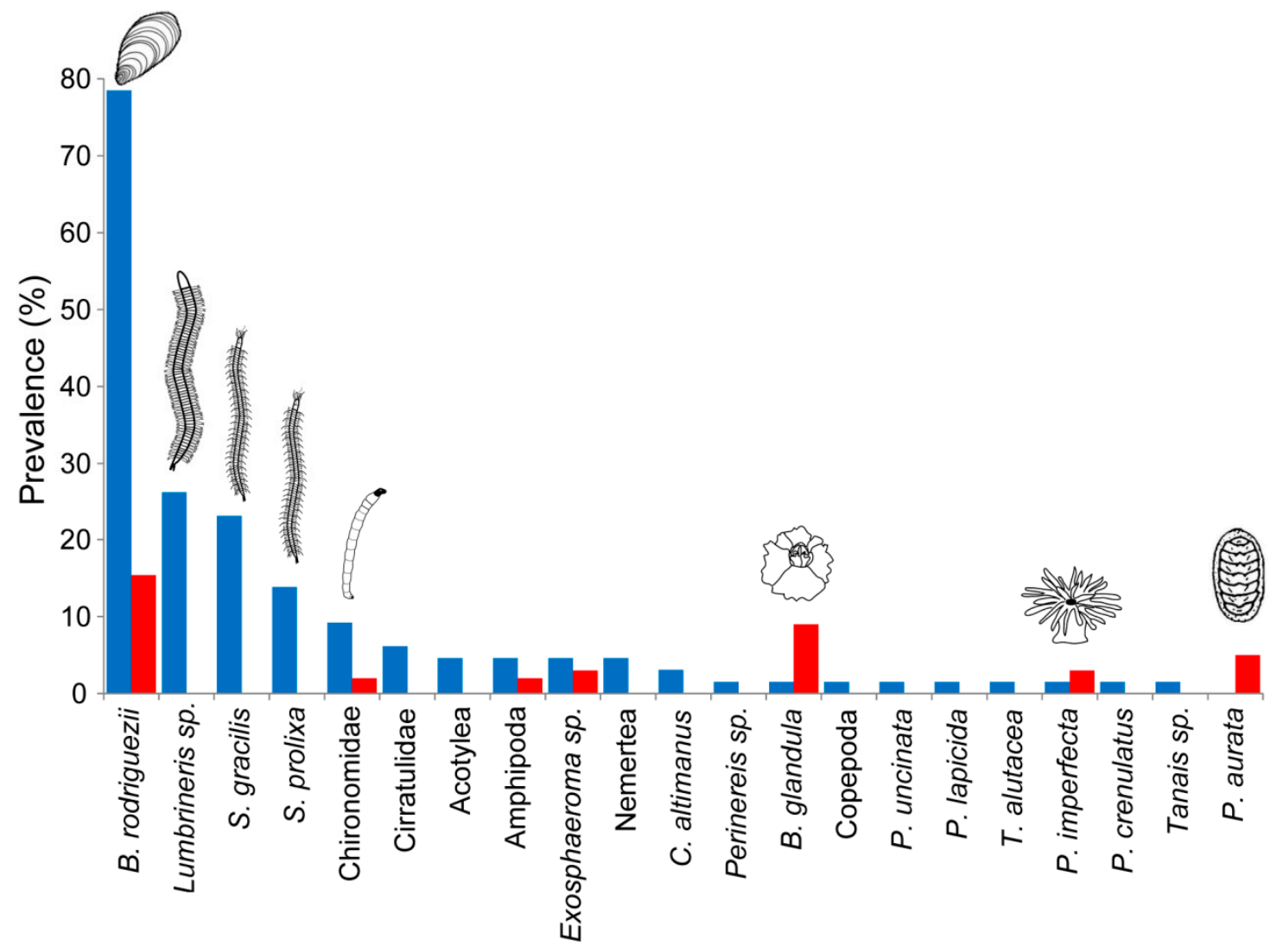

Figure 3. Prevalence (\% of samples with species present) of invertebrate species in Petricola-engineered (blue bars) and unengineered (red bars) patches. The most frequent species in the two different habitats are represented by an icon (see text in Results). 


\subsection{Invertebrate Species Richness as a Function of Sampled Area}

We found 416 boreholes in the 65 sample quadrats from Petricola-engineered patches (mean $=6.38$ ind $100 \mathrm{~cm}^{-2}, \mathrm{SD}=3.29$ ). Their aggregate surface area was estimated to be $0.76 \mathrm{~m}^{2}$ (i.e., assuming a constant borehole depth of $4 \mathrm{~cm}$; see Methods). The rock surface area between boreholes (i.e., total quadrat area minus the area covered by borehole openings) was estimated to be $0.6 \mathrm{~m}^{2}$. Based on these estimates, the total rock surface area sampled in Petricola-engineered patches was $1.36 \mathrm{~m}^{2}$ $(0.6+0.76)$. In the absence of boreholes, the total area sampled would be $0.65 \mathrm{~m}^{2}$ (i.e., 65 quadrats, $10 \mathrm{~cm}$ side each). This indicates that Petricola boreholes cause a $117 \%$ increase in rock surface area.

The accumulation curves relating observed species richness to rock surface area indicate that, for an equal surface area of $0.65 \mathrm{~m}^{2}$ (i.e., the total area sampled in unengineered patches), species richness is higher inside boreholes than on the rock surface of unengineered areas (Figure $2 b$, no overlap between confidence intervals at $0.65 \mathrm{~m}^{2}$ rock surface).

The mean number of species per $100 \mathrm{~cm}^{2}$ surface area was higher inside boreholes (mean $1.96 \pm 1.79)$ than in the unengineered rock surface $(0.38 \pm 0.49)$ (Welch's $t$-test: $t=8.92, d f=117$, $P<0.001)$.

\subsection{Invertebrate Species Composition in Petricola-Engineered Patches and Mussel Beds}

Twenty-two invertebrate species were found in the mussel beds samples from the upper platform (Table 1; the species accumulation curve for this habitat was asymptotic, suggesting sufficient sampling, see Supporting Materials, Figure S2: Species accumulation curve in mussel beds). Thirteen of the species in the mussel beds were also found in the Petricola-engineered habitat while the remaining nine species were exclusive of the mussel habitat (Table 1). Partial overlap (POij) in the observed data was thus 65 . This value lay below the upper $5 \%$ percentile of POij values of the randomized matrices (i.e., $85)$, which indicates that the species associated to the Petricola-engineered habitat are not a significant subset of those occurring in the mussel beds $(P=0.96)$.

\section{Discussion}

Our results show a threefold increase in the species richness of the low intertidal zone associated with the presence of boreholes made by Petricola dactylus. Yet, this is likely an underestimate provided that our species accumulation curves suggest that further sampling would lead to additional species records in the Petricola-engineered habitat but not in the unengineered one (see Figure 2a). This indicates that vacant $P$. dactylus boreholes are essential microhabitats for the maintenance of biodiversity within the otherwise inhospitable low platform.

The increased species richness of Petricola-engineered patches cannot simply be explained as an effect of the surface area added by boreholes. Indeed, species richness was also higher in engineered patches than unengineered ones when analyzed as a function of the surface area sampled (see Figure $2 b$ ). This indicates that the species richness of engineered patches is controlled by favorable environmental conditions within boreholes rather than increased rock surface area.

Vacant bivalve boreholes in intertidal platforms can protect other organisms from the impacts of desiccation, hydrodynamic forces, and predators, and also retain sediments that may be critical for the infauna $[5,43,44]$. Here, we anticipated that hydrodynamic forces and sediment scour should limit invertebrate colonization in the low platform (cf., unlikely importance of desiccation and predators; see Study Site and Organisms). In addition, we postulated that the retention of sediment within boreholes should favor infaunal colonization (see Introduction). In agreement, our results suggest that the increased richness of Petricola-engineered patches results from reduced water flow and sediment trapping/stabilization within boreholes. This is supported by the fact that only species with strong adhesion mechanisms (barnacles, chitons, sea anemones) were frequent on unengineered rock surfaces while vagile species poor in adhesion mechanisms and, therefore, prone to being washed out by waves (e.g., polychaetes, nemerteans, small crustaceans) were restricted to boreholes in most cases (see Table 1 
and Figure 3). Furthermore, the species restricted to boreholes included an array of infaunal and/or deposit-feeding taxa (e.g., polychaetes, tanaidaceans, chironomid larvae; see Table 1), which rely on stable sediments as habitat and/or food. In the absence of boreholes, infaunal and/or weakly adhesive vagile species would not withstand the harsh hydrodynamic regime and the concomitant sediment instability and scour that characterize the low platform.

The species in Petricola-engineered habitat are not a significant subset of those inhabiting mussel beds in the upper platform. Although both habitats share some infaunal (e.g., Lumbrineris sp., Syllis spp., Tanais sp., nemerteans) or interstitial species (e.g., Cyrtograpsus altimanus), several other species were exclusively found in Petricola-engineered patches (see Table 1). Therefore, Petricola-engineered patches extend the distribution of upper platform species into the lower platform but also promote the presence of species that do not occur in the former. These species are probably not adapted to the longer emersion periods that characterize the upper platform and are therefore limited to lower intertidal levels. By facilitating these species, Petricola dactylus could be increasing the overall species richness of the intertidal zone at this site.

By creating protected microhabitats within a harsh physical setting, physical ecosystem engineers can increase the extent of suitable habitat for other species (e.g., $[2,16])$. In the particular case of rocky shores, the high intertidal zone has been typically considered a harsh environment where air exposure and desiccation are maximum $[9,17,18]$ and where ecosystem engineers that buffer these physical conditions can be critical for other species (e.g., $[9,20])$. The low intertidal zone, on the other hand, is generally considered a physically benign habitat where ecosystem engineers facilitate the occurrence of other species via the provision of refugia from predators or competitors (e.g., [43,44]). However, this may not be the case of our low platform. Here, physical factors (i.e., hydrodynamics and sediment transport/scour) apparently override any biotic influence on species colonization (see Study Site and Organisms). Hence, the positive influence of Petricola-engineered microhabitats on species richness could largely be attributed to amelioration of physical conditions rather than the provision of enemy-free space. Experiments would ultimately be necessary to evaluate the above prediction.

Finally, our findings add to a few recent studies illustrating positive contributions of boring organisms to coastal species richness via the creation of boreholes $[5,44,45]$. Boring organisms have traditionally been viewed as bioeroders that can compromise the stability and persistence of habitats such as coastal rock, corals, and wood, with potential to reduce biodiversity [46-48]. Yet, bioerosion rates have rarely been compared to the rates of basal habitat formation (e.g., coral or wood production) and/or destruction due to other factors (e.g., physical rock erosion, coral reef degradation due to disease or acidification). If bioerosion is not a significant source of basal habitat loss (e.g., [22]), then boring organisms should better be construed as sources of microhabitat diversity and, thus, as potential benefactors of biodiversity. Further surveys and experiments will certainly be necessary to evaluate if the effects of boring organisms are also positive at other habitat types (e.g., coral reefs) and/or when considering boring species that substantially differ in borehole traits (e.g., size, shape, persistence).

Supplementary Materials: The following are available online at http:/ /www.mdpi.com/1424-2818/11/3/39/s1, Figure S1: Barren rock surface in the lower platform, without (a) and with (b) accumulated sand. Figure S2: Species accumulation curve in mussel beds at the upper platform.

Author Contributions: M.B., J.L.G., and M.G.P. conceived and designed the study. M.B., L.P.A., and J.L.G. carried out the field research and sample analysis. M.B. analyzed the data and wrote manuscript drafts with input from J.L.G. L.P.A. and M.G.P. contributed to interpretation of findings and commented on manuscript drafts. All authors read and approved the final manuscript.

Funding: This research was funded by CONICET (Consejo Nacional de Investigaciones Científicas y Técnicas; PIP 11220110100024) to M.G.P. and J.L.G., ANPCyT (Agencia Nacional de Promoción Científica y Técnica; PICT-2015-2468) to M.G.P., and PADI Foundation (No. 21703) to M.B. M.B. and L.P.A. were supported by CONICET fellowships.

Acknowledgments: We thank Félix Azara Foundation for housing in Punta Bermeja Reserve during field trips, and Sonia Landro, Sabrina Soria, Juliana González, and Carlos Sánchez Antelo for field assistance. Two anonymous reviewers improved the manuscript with their comments. Fieldwork was conducted with permission from Río 
Negro Province (Secretaría de Ambiente y Desarrollo Sustentable, Res. No 1142). This is a contribution to the program of GrIETA.

Conflicts of Interest: The authors declare no conflict of interest. The funders had no role in the design of the study; in the collection, analyses, or interpretation of data; in the writing of the manuscript; or in the decision to publish the results.

\section{References}

1. Bertness, M.D.; Hacker, S.D. Physical stress and positive associations among marsh plants. Am. Nat. 1994, 144, 363-372. [CrossRef]

2. Crain, C.M.; Bertness, M.D. Ecosystem engineering across environmental gradients: Implications for conservation and management. BioScience 2006, 56, 211-218. [CrossRef]

3. Badano, E.; Jones, C.; Cavieres, L.; Wright, J. Assessing impacts of ecosystem engineers on community organization: A general approach illustrated by effects of a high-Andean cushion plant. Oikos 2006, 115, 369-385. [CrossRef]

4. Silliman, B.R.; Bertness, M.D.; Altieri, A.H.; Griffin, J.N.; Bazterrica, M.C.; Hidalgo, F.J.; Crain, C.M.; Reyna, M.V. Whole-community facilitation regulates biodiversity on Patagonian rocky shores. PLoS ONE 2011, 6, e24502. [CrossRef] [PubMed]

5. Bagur, M.; Gutiérrez, J.L.; Arribas, L.P.; Palomo, M.G. Complementary influences of co-occurring physical ecosystem engineers on species richness: Insights from a Patagonian rocky shore. Biodivers. Conserv. 2016, 25, 2787-2802. [CrossRef]

6. Jones, C.G.; Lawton, J.H.; Shachak, M. Organisms as ecosystem engineers. Oikos 1994, 69, 373. [CrossRef]

7. Jones, C.G.; Lawton, J.H.; Shachak, M. Positive and negative effects of organisms as physical ecosystem engineers. Ecology 1997, 78, 1946-1957. [CrossRef]

8. Gálvez Bravo, L.; Belliure, J.; Rebollo, S. European rabbits as ecosystem engineers: Warrens increase lizard density and diversity. Biodivers. Conserv. 2009, 18, 869-885. [CrossRef]

9. Bertness, M.D.; Leonard, G.H.; Levine, J.M.; Schmidt, P.R.; Ingraham, A.O. Testing the relative contribution of positive and negative interactions in rocky intertidal communities. Ecology 1999, 80, 2711. [CrossRef]

10. Castilla, J.; Lagos, N.; Cerda, M. Marine ecosystem engineering by the alien ascidian Pyura praeputialis on a mid-intertidal rocky shore. Mar. Ecol. Prog. Ser. 2004, 268, 119-130. [CrossRef]

11. Borthagaray, A.I.; Carranza, A. Mussels as ecosystem engineers: Their contribution to species richness in a rocky littoral community. Acta Oecol. 2007, 31, 243-250. [CrossRef]

12. Foster, B.A. Desiccation as a factor in the intertidal zonation of barnacles. Mar. Biol. 1971, 8, 12-29. [CrossRef]

13. Garrity, S.D. Some adaptations of gastropods to physical stress on a tropical rocky shore. Ecology 1984, 65, 559-574. [CrossRef]

14. Harley, C.D.G.; Helmuth, B.S.T. Local- and regional-scale effects of wave exposure, thermal stress, and absolute versus effective shore level on patterns of intertidal zonation. Limnol. Oceanogr. 2003, 48, 1498-1508. [CrossRef]

15. Teagle, H.; Hawkins, S.J.; Moore, P.J.; Smale, D.A. The role of kelp species as biogenic habitat formers in coastal marine ecosystems. J. Exp. Mar. Biol. Ecol. 2017, 492, 81-98. [CrossRef]

16. Bertness, M.D.; Crain, C.M.; Silliman, B.R.; Bazterrica, M.C.; Reyna, M.V.; Hildago, F.; Farina, J.K. The community structure of Western Atlantic Patagonian rocky shores. Ecol. Monogr. 2006, 76, 439-460. [CrossRef]

17. Connell, J.H. The influence of interspecific competition and other factors on the distribution of the barnacle Chthamalus stellatus. Ecology 1961, 42, 710-723. [CrossRef]

18. Connell, J.H. Community interactions on marine rocky intertidal shores. Annu. Rev. Ecol. Syst. 1972, 3, 169-192. [CrossRef]

19. Dayton, P.K. Competition, disturbance, and community organization: The provision and subsequent utilization of space in a rocky intertidal community. Ecol. Monogr. 1971, 41, 351-389. [CrossRef]

20. Bertness, M.D.; Leonard, G.H. The role of positive interactions in communities: Lessons from intertidal habitats. Ecology 1997, 78, 1976. [CrossRef]

21. Coan, E.V. Recent species of the genus Petricola in the eastern Pacific (Bivalvia: Veneroidea). Veliger 1997, 40, 298-340. 
22. Bagur, M.; Gutiérrez, J.L.; Arribas, L.P.; Palomo, M.G. Endolithic invertebrate communities and bioerosion rates in southwestern Atlantic intertidal consolidated sediments. Mar. Biol. 2014, 161, 2279-2292. [CrossRef]

23. Scarabino, F.; Zelaya, D.G.; Orensanz, J.M.; Ortega, L.; Defeo, O.; Schwindt, E.; Carranza, A.; Zaffaroni, J.C.; Martínez, G.; Scarabino, V. Cold, warm, temperate and brackish: Bivalve biodiversity in a complex oceanographic scenario (Uruguay, southwestern Atlantic). Am. Malacol. Bull. 2015, 33, 284-301. [CrossRef]

24. Sunamura, T. Rocky coast processes: With special reference to the recession of soft rock cliffs. Proc. Jpn. Acad. Ser. B Phys. Biol. Sci. 2015, 91, 481-500. [CrossRef] [PubMed]

25. Zavala, C.; Freije, H. Geología de los acantilados. In Las Mesetas Patagónicas que Caen al Mar: La Costa Rionegrina; Massera, R.F., Lew, J., Serra Pairano, G., Eds.; Gobierno de Río Negro: Viedma, Argentina, 2005; pp. 187-199. ISBN 987-22604-0-0.

26. Andreis, R.R. Petrografía y Paleocorrientes de la Formación Río Negro (Tramo General Conesa-Boca del Río Negro). Ph.D. Thesis, Facultad de Ciencias Naturales y Museo, La Plata, Argentina, 1965; pp. 245-310.

27. Arribas, L.P.; Gutiérrez, J.L.; Bagur, M.; Soria, S.A.; Penchazadeh, P.E.; Palomo, M.G. Variations in aggregate descriptors of rocky shore communities: A test of synchrony across spatial scales. Mar. Biol. 2019, 166, 44. [CrossRef]

28. Arribas, L.P.; Bagur, M.; Klein, E.; Penchaszadeh, P.E.; Palomo, M.G. Geographic distribution of two mussel species and associated assemblages along the northern Argentinean coast. Aquat. Biol. 2013, 18, 91-103. [CrossRef]

29. Arribas, L.P.; Bagur, M.; Gutiérrez, J.L.; Palomo, M.G. Matching spatial scales of variation in mussel recruitment and adult densities across southwestern Atlantic rocky shores. J. Sea Res. 2015, 95, 16-21. [CrossRef]

30. Trovant, B.; Orensanz, J.L.; Ruzzante, D.E.; Stotz, W.; Basso, N.G. Scorched mussels (Bivalvia: Mytilidae: Brachidontinae) from the temperate coasts of South America: Phylogenetic relationships, trans-Pacific connections and the footprints of Quaternary glaciations. Mol. Phylogenet. Evol. 2015, 82, 60-74. [CrossRef] [PubMed]

31. Trenhaile, A.S.; Kanyaya, J.I. The role of wave erosion on sloping and horizontal shore platforms in macro-and mesotidal environments. J. Coast. Res. 2007, 298-309. [CrossRef]

32. Dickson, M.E.; Pentney, R. Micro-seismic measurements of cliff motion under wave impact and implications for the development of near-horizontal shore platforms. Geomorphology 2012, 151, 27-38. [CrossRef]

33. Paine, R.T. Food web complexity and species diversity. Am. Nat. 1966, 100, 65-75. [CrossRef]

34. Breitburg, D.L. Residual effects of grazing: Inhibition of competitor recruitment by encrusting coralline algae. Ecology 1984, 65, 1136-1143. [CrossRef]

35. Gotelli, N.J.; Colwell, R.K. Quantifying biodiversity: Procedures and pitfalls in the measurement and comparison of species richness. Ecol. Lett. 2001, 4, 379-391. [CrossRef]

36. Wiens, J.A. Spatial scaling in ecology. Funct. Ecol. 1989, 3, 385-397. [CrossRef]

37. Colwell, R.K.; Chao, A.; Gotelli, N.J.; Lin, S.-Y.; Mao, C.X.; Chazdon, R.L.; Longino, J.T. Models and estimators linking individual-based and sample-based rarefaction, extrapolation and comparison of assemblages. J. Plant Ecol. 2012, 5, 3-21. [CrossRef]

38. Colwell, R.K. EstimateS: Statistical Estimation of Species Richness and Shared Species from Samples. Version 9. 2013. Available online: http:/ / purl.oclc.org/estimates (accessed on 30 January 2019).

39. Zar, J.H. Biostatistical Analysis, 4th ed.; Prentice Hall: Upper Saddle River, NJ, USA, 1999; pp. 128-129. ISBN 0-13-081542-x.

40. Chao, A. Non-parametric estimation of the number of classes in a population. Scand. J. Stat. 1984, 11, 265-270.

41. Almeida-Neto, M.; Guimarães, P.; Guimarães, P.R., Jr.; Loyola, R.D.; Ulrich, W. A consistent metric for nestedness analysis in ecological systems: Reconciling concept and measurement. Oikos 2008, 117, 1227-1239. [CrossRef]

42. Guimarães, P.R., Jr.; Guimarães, P. Improving the analyses of nestedness for large sets of matrices. Environ. Model. Softw. 2006, 21, 1512-1513. [CrossRef]

43. Menge, B.A.; Lubchenco, J. Community organization in temperate and tropical rocky intertidal habitats: Prey refuges in relation to consumer pressure gradients. Ecol. Monogr. 1981, 51, 429-450. [CrossRef]

44. Pinn, E.H.; Thompson, R.C.; Hawkins, S.J. Piddocks (Mollusca: Bivalvia: Pholadidae) increase topographical complexity and species diversity in the intertidal. Mar. Ecol. Prog. Ser. 2008, 355, 173-182. [CrossRef] 
45. Hendy, I.W.; Michie, L.; Taylor, B.W. Habitat creation and biodiversity maintenance in mangrove forests: Teredinid bivalves as ecosystem engineers. PeerJ 2014, 2, e591. [CrossRef] [PubMed]

46. Evans, J.W. The role of Penitella penita (Conrad 1837) (Family Pholadidae) as eroders along the Pacific coast of North America. Ecology 1968, 49, 156-159. [CrossRef]

47. Hutchings, P.A. Biological destruction of coral reefs, a review. Coral Reefs 1986, 4, 239-252. [CrossRef]

48. Horonjeff, R.; Patrick, D. Action of marine borers and protective measures against attack. Coast. Eng. Proc. 1951, 1, 8. [CrossRef]

(C) 2019 by the authors. Licensee MDPI, Basel, Switzerland. This article is an open access article distributed under the terms and conditions of the Creative Commons Attribution (CC BY) license (http:/ / creativecommons.org/licenses/by/4.0/). 